\title{
MAJAS DAN CITRAAN DALAM PUISI "MISHIMA" KARYA GOENAWAN MOHAMAD (KAJIAN STILISTIKA)
}

\author{
Dwi Septiani ${ }^{1}$ \\ Dosen Program Studi Sastra Indonesia Fakultas Sastra Universitas Pamulang ${ }^{1}$ \\ dosen01401@unpam.ac.id ${ }^{1}$
}

\begin{abstract}
Abstrak
Tujuan penelitian ini adalah untuk menjabarkan berbagai majas serta citraan yang ada pada puisi "Mishima". Puisi tersebut adalah salah satu puisi di dalam antologi puisi berjudul Fragmen karya Goenawan Mohamad yang terbit tahun 2016 dan diterbitkan oleh Gramedia Pustaka Utama. Pendekatan yang digunakan dalam kajian ini adalah pendekatan stilistika. Metode yang dipakai dalam kajian ini adalah metode deskriptif analisis dengan semiotik. Data penelitian ini adalah data deskriptif, yakni data berupa kata, frasa, dan kalimat dalam puisi berjudul "Mishima" karya Goenawan Muhamad. Hasil penelitian ini membuktikan adanya wujud penggunaan majas dan citraan yang sangat bervariatif. Berdasarkan analisis data, diperoleh hasil sebagai berikut. Pertama, majas yang paling dominan adalah majas personifikasi yang ada pada bagian 2, 4, 5, 6, dan 7. Majas kedua yang dominan adalah majas simile yanga ada pada bagian 1, 2, 5, dan 7. Majas ketiga yang dominan adalah majas repetisi pada bagian 1, 3, 5, dan 6. Majas keempat yang dominan adalah majas pada bagian 5 dan 6 . Terakhir, ada pula muncul majas litotes, hiperbola, dan retoris. Kedua, citraan yang dominan muncul pada puisi "Mishima" karya Goenawan Mohamad adalah citraan penglihatan. Citraan pertama yang paling dominan adalah citraan penglihatan pada bagian 1, 6, dan 7. Citraan penglihatan yang ada dalam puisi ini berperan untuk menyampaikan visualisasi yang jernih atas sifat dan perilaku tokoh yang ada dalam puisi ini sehingga pembaca puisi ini seakan mampu membayangkan atau melihat kejadian itu. Selain citraan penglihatan, citraan kedua yang dominan adalah citra perabaan yang ada pada bagian 1 dan 3. Citraan ketiga yang dominan adalah citraan pendengaran dan citra penciuman yang ada pada bagian 5 .
\end{abstract}

\section{Kata Kunci: Majas, Citraan, Stilistika, Puisi, Goenawan Mohamad}

\section{Pendahuluan}

Sebuah karya sastra adalah struktur dari variasi kata dari seorang pengarang yang ditransmisikan kepada para pecinta sastra. Menurut Nurgiyantoro (2010: 272) bahwa bahasa adalah salah satu elemen terpenting dari sebuah karya sastra. Sama halnya dengan paparan dari Sudjiman (1993: 7), karya sastra merupakan wacana yang berbeda di mana ungkapan bahasa dimanfaatkan dengan sangat kemungkinan yang ada dengan maksimal. Saat mengkaji penggunaan bahasa dalam sebuah karya sastra, studi mengengai stilistika harus digunakan. Stilistika adalah studi yang menganalisis bahasa dalam karya sastra, khusunya menganalisis pemakaian bahasa yang ada pada sebuah karya sastra. Chvatik (dalam Aminuddin, 1995: 22) 
memaparkan bahwa studi stilistika mengkaji bahasa dalam teks sastra sebagai tanda estetik dengan analisis bidang stilistik dan memosisikan bahasa yang terdapat pada karya sastra sama halnya dengan aspek bahasa yang menjadi fokus dalam bidang linguistik. Bahasa dalam karya sastra yang diteliti dengan stilistika memiliki dua cara. Awalnya, penelitian stilistika dilakukan dengan memeriksa berbagai unsur linguistik dari karya sastra dan sumber-sumber terus menentukan sifat-sifatnya, mengingat tujuan estetika karya sastra sebagai hal yang dituju. Kedua, penelitian stilistika ini dilakukan dengan kemampuan untuk mempelajari berbagai ciri khusus, sehingga struktur bahasa dapat dibedakan dari beberapa struktur lainnya (Wellek, 1989: 226). Dari dua pendekatan ini, akan ada perbedaan.

Namun, kedua proses sangat penting dilakukan. Salah satu karya sastra yang dapat dipelajari dengan stilistika adalah puisi. Menurut Pradopo (2010: v), puisi adalah pernyataan sastra yang paling penting. Karya sastra puisi tidaklah sama dengan prosa dan drama. Karya sastra puisi sangat konsentris dan kuat dalam strukturnya. Penulis tidak lagi secara detail mengungkapkan segala hal dalam elemen apa yang harus ditransmisikan kepada pembaca. Puisi berjudul "Mishima" karya Goenawan Muhamad bahwa ada variasi bahasa yang menarik untuk dipelajari lebih lanjut. Inilah yang mendorong peneliti untuk mencari keunikan bahasa yang digunakan oleh Goenawan Muhamad dalam menyampaikan pesan puisi tersebut. Bahasa adalah instrument yang kuat dalam hal penyampaian sebuah ide kreatif dari pengarang yang diwujudkannya dalam sebuah karya sastra.

Dari berbagai studi yang telah banyak dilakukan saat ini, dapat dilihat bahwa penelitian tentang majas dengan studi stilistika telah dipelajari secara luas. Meskipun ada banyak penelitian tentang majas dan citraan dengan studi stilistika, peneliti berpikir bahwa pencarian serupa masih perlu dilakukan. Hal ini dilakukan oleh peneliti untuk melengkapi dan memperkaya studi stilistika sebelumnya. Penelitian ini menggunakan teori yang relevan untuk membantu analisis yang ingin dicapai.

Teori yang digunakan adalah kajian tentang gaya bahasa dan citraan. Sudjiman (1993: 3) berpendapat bahwa studi statistika adalah studi tentang penggunaan bahasa dan gaya bahasa dalam sebuah karya sastra. Wellek (1989: 229) menyatakan bahwa analisis gaya bahasa akan memberikan hasil yang luar biasa bagi pembelajaran sastra jika terdapat prinsip yang mendasari keutuhan karya sastra, dan jika ditemukannya tujuan estetika standar yang menonjol dalam sebuay karya sastra. Kajian tentang gaya bahasa diarahkan untuk fokus 
mengupas tentang isi karya sastra tersebut. Secara umum, Aminuddin (1995: 1) menyatakan bahwa gaya adalah perwujudan dari penggunaan bahasa si pencipta untuk mendeskripsikan ide, pendapat, dan mampu menghasilkan konsekuensi tertentu bagi penikmat karyanya. Sejalan dengan hal tersebut, menurut Yono dan Mulyani (2017: 201), dalam dunia sastra, permasalahan gaya dalam prosesn penyampaian adalah sesuatu yang paling memperlihatkan adanya tujuan kepengarangan seseorang, dan juga memperlihatkan adanya perbedaan antara satu karya sastra dengan karya sastra yang lainnya.

Aspek-aspek yang dipertimbangan, salah satunya adalah aspek fonologis (alitrasi, irama, dan efek bunyi tertentu). Selain itu, ada pula majas dan citraan. Majas kerap disebut dengan frasa gaya bahasa. Akan tetapi, gaya bahasa adalah payung besar yang di dalamnya ada berbagai kajian; salah satunya adalah pembahasan tentang majas. Menurut Ratna (2009: 164), majas adalah rangkaian elemen khusus dalam gaya bahasa. Oleh karena itu, dapat disebutkan bahwa kajian gaya bahasa jauh lebih kompleks dibandingkan dengan kajian mengenai majas.

Majas memiliki ciri khusus sehingga pola-pola majas tersebut tampak mengurangi adanya usaha kreatif dalam berbahasa. Dalam Kamus Besar Bahasa Indonesia Edisi $V$ Daring, majas merupakan suatu cara untuk melukiskan sesuatu dengan jalan menyamakannya dengan sesuatu yang lain atau biasa disebut dengan bahasa kiasan. Variasi majas yang ada dalam sebuah puisi sangat berperan menimbulkan berbagai efek yang ingin disampaikan oleh penulis.Dengan adanya penggunaan majas dalam sebuah karya sastra, dapat membuat penikmat karya sastra dapat menjadi lebih menikmati karena bahasa dalam karya sastra lebih menarik. Permajasan, menurut Nurgiyantoro (2010: 297), adalah adalah metode penggunaan bahasa yang lebih condong pada penggunaan bahasa yang bermakna tersirat. Oleh sebab itu, sebagai penikmat karya sastra diharapkan mampu dengan teliti dan jeli berbagai bentuk makna, ekspresi, serta adanya gambaran atau visualisasi yang ada.

Karakteristik majas adalah mampu membuat efek sugestif yang makin kaya, efektif, serta makin tinggi terhadap pemaknaan sebuah karya sastra. Pradopo (2010: 62) menyampaikan bahwa majas dalam karya sastra berfungsi memikat perhatian, menciptakan kebaruan yang mampu mewujudkan kecermatan pemaparan sebuah angan. Abram (dalam Supriyanto 2011: 68) memaparkan bahwa majas sama halnya dengan istilah bahasa kias. Bahasa kias sendiri terdiri dari perbandingan, metafora, metonimi, sinekdoki, dan 
personifikasi. Di sisi lain, Pradopo (2010: 62) menyebutkan bahwa bahasa kias dapat diklasifikasikan menjadi tujuh jenis, yaitu simile (perumpamaan), metafora, perumpamaan epik, personifikasi, metonimia, sinekdoki, dan alegori. Fananie (2000: 37-40) memaparkan bahwa jenis majas bermacam-macam, misalnya persamaan atau simile, metafora, personifikasi, alusio, eponim, epitet, alegori, sinekdoke, metonimia, hipalase, inuenda, antifrasis, paranomasia, ironi, sinisme, dan sarkasme. Namun, Nurgiyantoro (2010: 298300) jauh lebih sederhana memaparkan berbagai jenis majas, misalnya simile, metafora, dan personifikasi. Selain itu, gaya pemajasan lain yang kerap ditemui dalam berbagai karya sastra adalah metonimia, sinekdoke, hiperbola, dan paradoks. Berdasarkan pemaparan tentang ragam di atas, dapat disebutkan bahwa penggunaan majas sangatlah banyak dan para ahli membuat klasifikasi yang tidak sama.

Selain majas, hal yang akan dikaji adalah citraan. Citraan adalah aspek penting untuk merangsang indra pembaca dengan berbagai penggunaan ekspresi bahasa tertentu. Pembaca diajak untuk mampu membayangkan apa yang telah dilihat, didengar, atau dirasakan tentang beberapa elemen di dalam karya tersebut. Nurgiyantoro (2010: 304) menyatakan bahwa citraan adalah penggunaan kata-kata atau ungkapan dalam karya sastra yang memiliki fungsi penting untuk membangkitkan respons sensorik penikmat karya sastra.

Pradopo (2010:79-80) memaparkan bahwa citraan merupakan rangkaian gambar yang terdapat di dalam ide atau pikiran dan bahasa yang menjadi alat untuk menggambarkan ide tersebut dan setiap citraan dari pemikiran tersebut dikenal sebagai citra atau imaji. Gambaran dari gagasan tersebut adalah pengaruh dalam pikiran yang secara hati-hati menyerupai apa yang dihasilkan oleh pemaknaan dari pembaca terhadap objek yang dapat ditangkap oleh mata, saraf penglihatan, dan terkait pula dengan kinerja otak. Gambaran pikiran merupakan sebuah efek yang muncul dalam pikiran dan sangat identik seolah pembaca atau pendengar mampu menangkan suatu objek yang dapat dilihat oleh pancaindra Sejalan dengan hal tersebut, Nurgiyantoro (2010:81) juga mengemukakan jenis citraan menjadi lima, yakni citraan penglihatan (visual), citraan pendengaran (auditoris), citraan peraba (taktil termal), citraan penciuman (olfaktori), dan citraan gerak (kinestetik). Berdasarkan pemaparan di atas, dapat disimpulkan bahwa citraan adalah sebuah visualisasi dari berbagai gambaran sensoris yang mampu terwujud dari kata-kata yang dibaca dan 
didengar. Dalam penulisan karya sastra, unsur citraan merupakan suatu gaya yang unik dimanfaatkan oleh penulis atau pengarang.

\section{Metode Penelitian}

Dalam kajian stilistika ini, pendekatan stilistika adalah pendekatan yang digunakan. Selain itu, metode yang digunakan adalah metode deskriptif analisis dengan bidan kajian semiotik. Puisi "Mishima" karya Goenawan Mohamad digunakan sebagai data inti penelitian. Teknik pengumpulan data yang digunakan dalam penelitian ini ialah teknik pustaka dan teknik pembacaan heuristik. Pengumpulan data melalui teknik pustaka dilakukan dengan cara memahami isi puisi "Mishima" karya Goenawan Mohamad, mencatat berbagai kata, frasa, dan kalimat yang mengandung majas dan citraan ke dalam bentuk tulis. Proses selanjutnya adalah sumber tertulis itu dilakukan pembacaan dengan teliti, lalu dipilih bagian puisi yang relevan sebagai data yang akan dikaji. Pemilihan data dilaksanakan dengan teknik pembacaan heuristik, yakni pembacaan menurut konvensi atau struktur bahasa atau dapat pula disebut sebagai pembacaan semiotik pada level pertama. Setelah mendapatkan data dan proses pembacaan tersebut, data-data digolongkan berdasarkan dua jenis tujuan penelitian, yaitu mendata adanya variasi majas dan citraan. Berdasarkan pembacaan secara cermat kemudian dilakukan pencatatan data yang berupa kata, kalimat yang mengandung majas dan citraan yang terdapat pada puisi "Mishima" karya Goenawan Mohamad dalam kartu data.

Analisis data dalam kajian ini menggunakan teknik pembacaan hermeneutik, yakni pembacaan semiotik pada tingkat atau level kedua. Tahap pertama pada pembacaan hermeneutik, yakni pembacaan kembali dengan memberikan interpretasi yang erat kaitannya dengan konvensi sastra. Pada saat, proses interpretasi dilakukan, sebaiknya berhubungan pula dengan kode bahasa, sastra, dan budaya karena ketiganya berperan penting membentuk sebuah karya sastra secara utuh. Tahap kedua adalah memaparkan variasi majas dan citraan yang ada pada puisi "Mishima" karya Goenawan Mohamad.

Kajian ini membahas studi stilistika yang mengutamakan pembahasan tentang majas dan citraan. Pendekatan yang digunakan dalam kajian ini adalah pendekatan stilistika dengan menganalisis sistem linguistik dalam sebuah karya sastra dan dengan menguraikan karakteristik tersebut. Strategi ini digunakan untuk mengkaji penggunaan majas dan citraan dalam puisi berjudul "Mishima" karya Goenawan Mohamad. Oleh karena itu, tujuan utama 
analisis ini adalah penggunaan karakteristik majas dan citraan dalam puisi tersebut. Dalam hal ini, yang dianalisis adalah data deskriptif, yakni data yang ada di dalam struktur kata, frasa, dan kalimat dalam puisi. Teknik analisis data yang dipakai adalah teknik analisis deskriptif kualitatif.

\section{Pembahasan}

Berdasarkan penelitian terhadap puisi berjudul "Mishima" karya Goenawan Mohamad dapat diketahui adanya penggunaan majas dan citraan yang sangat kompleks. Dalam aspek majas, ditemukan beberapa majas, yaitu simile, repetisi, personifikasi, polisidenton dan asindenton, litotes, metafora, hiperbola, dan juga pertanyaan retoris. Selain itu, pada aspek citraan, sajak ini mengandung citraan penciuman, perabaan, penglihatan, dan pendengaran. Data primer penelitian, yakni puisi berjudul "Mishima" karya Goenawan

Mohamad. Pada puisi tersebut, ada tujuh bagian.

\section{Mishima}

Seperti pengungsi dari gempa, Mishima (aku bayangkan ia Mishima) pulang. Lanskap rusak. Tapi ia ingin bergerak, kemudian tua. Dan terbaring. Dan Mishima terbaring, menatap langit-langit, dari tikar yang disepuh musim. Rambutku hilang, ia berkata, rambutku hilang. Tapi lihat, aku tahu di mana aku tak akan ada lagi. Setumpuk arang panas menghangatkan kakinya.

$$
2
$$

Di detik-detik berikutnya, ruang itu mendengarkan jam: Siul cerek melengking dari didih air, sebelum dusun tertidur. Malam menyeduh teh, sup telah masak. Seolah-olah semua membiarkan kata-kata berhenti pada shoji.

3

Di luar Ashram, tiga hantu dari kuil memukulkan beliung pada paras waktu dan berkata: Kau tahu, aku tahu, kita tahu.

Aku bayangkan Mishima berkata: mimpi membujukku dengan luka Santo Sebastian Tujuh anak panah yang menembus tubuhnya yang berahi meregang di pusarku.

5

30 tahun yang lalu aku pernah bersamamu ke Yudanaka dengan kereta api pelan. Oktober meminta kita menghirup warna daun. Tapi kau menyanyi kecil dan membuka kutang, dan dua jam kemudian di tepi bak air panas, kutemukan namamu yang terhapus. Minum, kau berbisik. Minum. Tattoo di lengan itu mengeriput seperti daun terakhir. Tubuhmu sebuah kemarau: anasir dan peristiwa yang tak menyentuh lagi.

$$
6
$$

Seharusnya aku Narsisus dengan tukak lambung yang tak bercermin ke wajah air. Seharusnya aku Narsisus dengan amis ikan yang meludah dan bersetubuh di kolam itu dengan arwah dan humus hutan. Mungkin aku tak kenal sakit hati yang membalas. Aku membaca tiap frase mitologi, aku selalu ingin melengkapi: pedang dengan matahari. kembang dengan keringat, sungai dengan sperma yang tipis tertahan. Apa yang tak bisa kita cintai sebenarnya dari carut-marut bumi? Seharusnya aku Narsisus, yang memandang gerak-gerik mendung: burung-burung Yunani yang sewarna membentuk huruf. Tak punya arti Dan tak pernah menengok ke kolam.

$$
7
$$

Lewat pintu geser. Mishima seakan melihat mereka, dalam asap rokok: Kelasi kapal-kapal yang kalah yang disembunyikan di kotak waktu. Rumah makan unagi ini tak mau mengungkapnya. Di lantai dua, tamu-tamu beku. Botolbotol beku. Di dinding ada kanvas: hutan Guadalkanal, pasir yang tak tersentuh perang. pematang yang naik turun, pengantin yang diusung ke tengah semak dengan nyanyian hampir mabuk. Tapi selalu ada orang yang seperti aku, kata Mishima, yang tak ingin cerita alternatif. Hari hanya satu narasi. Tuhan menamainya kematian. Dan Mishima terbaring, menatap langit-langit, dari tikar yang disepuh musim.

\section{Majas pada Puisi "Mishima"}


Majas pada puisi "Mishima" karya Goenawan Mohamad ini sangatlah bervariasi. Ada beberapa majas yang digunakan dalam puisi ini, misalnya saja majas metafora, repetisi, simile, personifikasi, litotes, dan retoris. Berikut ini adalah pembahasa tentang majas yang paling dominan dalam puisi "Mishima.

Pertama, majas yang dominan adalah majas personifikasi. Majas personifikasi adalah majas yang paling dominan dalam puisi ini. Majas personifikasi yang ada pada bagian 2 dari puisi "Mishima". Dalam Kamus Besar Bahasa Indonesia Edisi V Daring (Online), majas personifikasi adalah pengumpamaan (pelambangan) benda mati sebagai orang atau manusia. Berikut ini adalah kutipan personifikasi pada bagian $2,4,5,6$, dan 7 .

\section{Di detik-detik berikutnya, ruang itu mendengarkan jam}

Siul cerek melengking dari didih air

Malam menyeduh teh

Aku bayangkan Mishima berkata: mimpi membujukku dengan luka Santo Sebastian

Oktober meminta kita menghirup warna daun

Seharusnya aku Narsisus, yang memandang gerak-gerik mendung

Rumah makan unagi ini tak mau mengungkapnya

Majas personifikasi ialah perbandingan benda mati yang seolah dihidupkan dengan menggunakan perilaku atau sifat manusia. Kata ruang di atas layaknya memiliki telinga sehingga dapat mendengarkan suara detak jam. Selain itu, frasa siul cerek melengking merupakan majas personfikasi. Makna siul dalam Kamus Besar Bahasa Indonesia Edisi V Daring adalah 'tiruan bunyi suling yang dilakukan dengan mulut'. Jadi, jelas bahwa cerek yang termasuk benda tidak bernyawa seolah dianggap memiliki mulut yang mampu bersiul.

Kedua, majas yang dominan adalah majas simile. Dalam Kamus Besar Bahasa Indonesia Edisi V Daring, majas simile adalah majas pertautan yang membandingkan dua hal yang secara hakiki berbeda, tetapi dianggap mengandung segi yang serupa, dinyatakan secara eksplisit dengan kata seperti, bagai, laksana. Berikut ini adalah kutipan majas simile pada bagian 1, 2, 5, dan 7 dalam puisi tersebut.

Seperti pengungsi dari gempa, Mishima (aku bayangkan ia Mishima) pulang 
Seolah-olah semua membiarkan kata-kata berhenti pada shoji. Tattoo di lengan itu mengeriput seperti daun terakhir

Mishima seakan melihat mereka, dalam asap rokok

Kata seperti, seolah-olah, dan seakan merupakan kata pembanding eksplisit untuk membandingkan sesuatu yang dibandingkan dengan pembandingnya. Pada bagian Seperti pengungsi dari gempa, Mishima (aku bayangkan ia Mishima) pulang tokoh Mishima pulang dengan menampakkan diri layaknya pengungsi dari gempa, kacau, dan terguncang. Selain itu, pada bagian Tattoo di lengan itu mengeriput seperti daun terakhir, kata tato diumpakan oleh penulisa seperti daun.

Ketiga, majas yang dominan adalah majas repetisi. Majas repetisi adalah majas yang paling dominan karena ditemukan pada bagian 1, 3, 5, dan 6 dari puisi tersebut. Dalam Kamus Besar Bahasa Indonesia Edisi V Daring, majas repetisi adalah gaya bahasa yang menggunakan kata kunci yang terdapat di awal kalimat untuk mencapai efek tertentu dalam penyampaian makna ulangan (sandiwara dan sebagainya). Berikut adalah kutipan majas repetisi pada bagian 1, 3, 5, dan 6:

Rambutku hilang, ia berkata, rambutku hilang.

Kau tahu, aku tahu, kita tahu.

Minum, kau berbisik. Minum.

Seharusnya aku Narsisus dengan tukak lambung... Seharusnya aku Narsisus dengan amis ikan... Seharusnya aku Narsisus, yang memandang gerak-gerik mendung

Kata-kata yang ditebalkan termasuk majas repetisi yang mengalami perulangan karena memiliki maksud untuk menekankan dan menegaskan pentingnya sesuatu yang dituturkan. Padahal, kata-kata tersebut tidak memiliki perbedaan makna antara satu dengan lainnya, mereka (kata-kata) tidak memiliki kriteria khusus.

Keempat, majas yang dominan adalah majas metafora. Majas metafora merupakan majas yang menggunakan kata atau frasa yang bermakna kiasan, tetapi hanya sebagai gambaran berlandaskan pada persamaan atau perbandingan. Majas tersebut ada pada bagian 5 dan 6 .

\section{Tubuhmu sebuah kemarau}


Aku membaca tiap frase mitologi, aku selalu ingin melengkapi: pedang dengan matahari. kembang dengan keringat, sungai dengan sperma yang tipis tertahan.

Bagian 5 dan 6 pada puisi "Mishima" di atas adalah jenis dari majas metafora. Kalimat Tubuhmu sebuah kemarau pada bagian 5 menyiratkan bahwa Tokoh Aku menyamakan tubuh seseorang dengan musim kemarau atau musim kering yang panas dan gersang. Selain itu, pada bagian 6 , cukup banyak bagian yang termasuk dalam majas metafora. Misalnya, saja penulis membandingkan antara pedang dengan matarhari. Kata pedang dan matahari adalah dua hal yang berbeda, tetapi memiliki kesamaan dari segi kekuatan yang ada pada kedua benda konkret tersebut. Pedang memiliki ketajaman dan kerap digunakan dalam alat peperangan tradisional, sedangkan matahari memiliki energi panas paling di semesta.

Kelima, ada pula muncul majas litotes, hiperbola, dan retoris. Dalam Kamus Besar Bahasa Indonesia Edisi V Daring, majas litotes adalah pernyataan yang memperkecil sesuatu atau melemahkan, dan menyatakan kebalikannya Kutipan litotes dan metafora pada bagian 1:

\section{Rambutku hilang, ia berkata, rambutku hilang}

Dari kutipan di atas, jelas terlihat bahwa majas litotes adalah majas yang mengandung sikap rendah diri. Kutipan di atas menjelaskan bahwa Rambutku hilang, ia berkata, rambutku hilang. Maksuda dari bagian di atas, tokoh mengungkapkan bahwa rambutnya telah rontok, tetapi

Majas hiperbola juga digunakan oleh Goenawan Mohamad pada bagian 7. Dalam Kamus Besar Bahasa Indonesia Edisi V Daring, hiperbol adalah ucapan (ungkapan, pernyataan) kiasan yang dibesar-besarkan (berlebih-lebihan), dimaksudkan untuk memperoleh efek tertentu. Berikut ini adalah kutipan yang mengandung majas hiperbol.

\section{Di lantai dua, tamu-tamu beku.}

Frasa tamu-tamu beku merupakan ungkapan yang menyatakan 'keadaan para tamu yang diam, bukan dalam keadaan membeku yang sebenarnya atau tidak 
bernyawa'. Tokoh Aku mengggambarkan keadaan para tamu yang diam, tidak melakukan aktivitas normal seperti biasanya.

Majas retoris adalah majas yang umumnya bertipe kalimat tanya, tetapi tidak perlu ada jawaban. Tujuan dari majas ini adalah memberikan penegasan, sindiran, atau menggugah. Kutipan pertanyaan retoris pada bagian 6 di bawah ini.

\section{Apa yang tak bisa kita cintai sebenarnya dari carut-marut bumi?}

Kutipan di atas merupakan pertanyaan yang memberikan kesempatan kepada pembaca untuk menjawabnya. Pertanyaan retoris tersebut memang tidak diperlukan adanya jawaban. Pengarang beranggapan bahwa pembaca sudah tahu jawaban dari pertanyaan majas retoris.

\section{Citraan pada Puisi "Mishima"}

Citraan adalah salah satu cara dalam mewujudkan adanya gambaran atau citra mental pribadi atau gambaran tentang sesuatu hal. Selain itu, citraan dapat juga disebut sebagai adanya kesan atau gambaran visual yang dapat muncul karena adanya kemunculan struktur bahaasa, mulai dari kata, frasa, atau kalimat, dan citraan ini umumnya menjadi aspek penting yang unik dalam sebuah karya sastra. Puisi adalah salah satu jenis karya sastra yang kerap memanfaatkan adanya citraan. Citraan yang dikreasikan oleh Goenawan Mohamad dalam puisi "Mishima" sangatlah unik. Ada beberapa citraan yang ditemukan dalam puisi tersebut, yakni citraan penciuman, penglihatan, perabaan, dan pendengaran. Berikut ini adalah pembahasan citraan yang paling dominan dalam puisi "Mishima" karya Goenawan Mohamad.

Pertama, citraan yang paling dominan adalah citraan penglihatan. Citraan penglihatan adalah citraan yang paling dominan digunakan dalam puisi "Mishima" karya Goenawan Mohamad ini. Citra penglihatan adalah citraan yang muncul karena adanya fungsi indra penglihatan atau mata. Citraan ini dapat dilihat pada bagian 1,6, dan 7:

Dan Mishima terbaring, menatap langit-langit, dari tikar yang disepuh musim Aku membaca tiap frase mitologi

Seharusnya aku Narsisus, yang memandang gerak-gerik mendung 
Mishima seakan melihat mereka, dalam asap rokok

Mishima terbaring, menatap langit-langit, dari tikar yang disepuh musim.

Kata menatap, membaca, memandang, dan melihat adalah kata awal dari tatap dan lihat. Kedua kata tersebut merupakan kelas kata verba atau kerja yang memiliki arti sebenarnya (denotasi) pada konteks kutipan tersebut. Alasan tersebutlah yang membuktikan bahwa kedua kata tersebut adalah citra penglihatan.

Kedua, citraan yang dominan adalah citra perabaan. Citra perabaan merupakan citraan yang dapat muncul oleh indra peraba (kulit). Ketika membaca atau mendengar larik-larik puisi, ditemukan kata, frasa, atau kalimat yang mampu membangkitkan hal yang dapat dirasakan kulit, misalnya kasar, lembut, hangat, dingin, dan lain-lain. Bagian puisi di atas yang terdapat citra perabaan ada pada bagian 1 dan 3:

Setumpuk arang panas menghangatkan kakinya

Di luar Ashram, tiga hantu dari kuil memukulkan beliung pada paras waktu

Penjelasan dari kata menghangatkan adalah setumpuk arang yang tengah dibakar, mengeluarkan hawa atau uap panas yang berlangsung cukup lama. Hawa tersebutlah yang bersentuhan dengan indra peraba kita, yaitu kulit. Kata "menghangatkan" adalah citra perabaan. Selanjutnya, kata memukulkan adalah kata kerja yang bermakna mengetuk sesuatu dengan keras yang umumnya menggunakan tangan.

Ketiga, citraan yang dominan adalah citraan pendengaran. Citraan jenis ini adalah citraan yang muncul dengan kata, frasa, atau kalimat yang mampu membayangkan adanya bunyi atau suara. Citraan ini dapat dilihat pada bagian 5:

\section{Tapi kau menyanyi kecil dan membuka kutang}

Minum, kau berbisik.

Frasa Menyanyi kecil dapat juga diasumsikan sebagai bersenandung. Keduanya sama-sama mengeluarkan frekuensi gelombang suara yang kecil. Namun, tidak berarti tidak terdengar. Aksi bersenandung atau bernyanyi kecil tersebut membuktikan bahwa kutipan di atas termasuk citra pendengaran. Selain itu, kata 
berbisik pada bagian 5 di atas dapat pula dimaksud sebagai berbicara yang dilakukan secara sangat perlahan.

Keempat, ada pula citra penciuman. Citra penciuman sangat erat dengan adanya efek atau kesan yang muncul karena adanya fungsi indra penciuman. Citraan ini akan muncul saat proses membaca atau mendengar berbagai kata khusus, lalu terbayanglah seolah mencium bau sesuatu. Citra penciuman terdapat pada bagian 5:

\section{Oktober meminta kita menghirup warna daun}

Kutipan di atas memberikan penjelasan bahwa musim gugur (Oktober) membuat masyarakatnya atau "Kita" menghirup aroma-aroma daun gugur. Citra penciuman terbukti dengan kata "menghirup" warna daun.

\section{Simpulan}

Berdasarkan analisis data, simpulan dalam penelitian ini adalah sebagai berikut. Pertama, majas yang paling dominan dalam puisi "Mishima" karya Goenawan Mohamad adalah majas personfikasi. Berikut ini adalah ringkasan majas yang paling banyak ditemukan dalam puisi tersebut. Majas dominan yang pertama adalah majas personifikasi yang ada pada bagian 2, 4, 5, 6, dan 7. Majas Kedua yang dominan adalah majas simile yanga ada pada bagian 1, 2, 5, dan 7. Majas ketiga yang dominan adalah majas repetisi pada bagian 1, 3, 5, dan 6. Majas keempat yang dominan adalah majas pada bagian 5 dan 6 . Terakhir, ada pula muncul majas litotes, hiperbola, dan retoris.

Kedua, citraan yang dominan muncul pada puisi "Mishima" karya Goenawan Mohamad adalah citraan penglihatan. Citraan pertama yang paling dominan adalah citraan penglihatan pada bagian 1, 6, dan 7. Citraan penglihatan yang ada dalam puisi ini berperan untuk menyampaikan visualisasi yang jernih atas sifat dan perilaku tokoh yang ada dalam puisi ini sehingga pembaca puisi ini seakan mampu membayangkan atau melihat kejadian itu. Selain citraan penglihatan, citraan kedua yang dominan adalah citra perabaan yanga ada pada bagian 1 dan 3. Citraan ketiga yang dominan adalah citraan pendengaran pada bagian 5 . Terakhir, citra penciuman yang ada pada bagian 5 . 


\section{Daftar Pustaka}

Aminuddin. 1995. Stilistika PengantarMemahami Bahasa dalam Karya Sastra. Semarang: IKIP

Semarang Press.

Fananie, Zainuddin. 2000. Telaah Sastra. Surakarta: Muhammadiyah University Press.

Mohamad, Goenawan. 2016. Fragmen. Jakarta: Gramedia Pustaka Utama.

Nurgiyantoro, Burhan. 2010. Teori Pengkajian Fiksi. Yogyakarta: Gadjah Mada University Press.

Pradopo, Rahmat Djoko. 2010. Pengkajian Puisi. Yogyakarta: Gadjah Mada University Press.

Ratna, Nyoman Kutha. 2009. Stilistika, Kajian Puitika Bahasa, Sastra, dan Budaya. Yogyakarta: Pustaka

Pelajar.

Tim Penyusun. Kamus Besar Bahasa Indonesia Edisi V Daring (Online). Tersedia di: http://bahasa.kemdiknas.go.id/kbbi/index.php. Diakses 20 Mei 2020.

Sudjiman, Panuti. 1993. Bunga Rampai Stilistika. Jakarta: Grafiti.

Supriyanto, Teguh. 2011. Kajian Stilistika dalam Prosa. Yogyakarta: Elmetera Publishing.

Wellek, Rene dan Austin Warren. 1989. Teori Kesusastraan. (Terj. Melani Budianta). Jakarta: Gramedia.

Yono, Robert Rizki, Mimi Mulyani. 2017. "Majas dan Citraan dalam Novel Kerling Si Janda Karya Taufiqurrahman Al-Azizy" Jurnal Seloka 6 (2) (2017), hlm. 200-207. 